\title{
Searching for the territorial origins of England
}

BRUCE EAgLes. From Roman Civitas to Anglo-Saxon Shire: topographical studies on the formation of Wessex. 2018. Oxford: Oxbow Books; 978-1-78570-984-5 £34.99

STEPHEN RIPPON. Kingdom, Civitas, and County. The evolution of territorial identity in the English landscape. 2018. Oxford: Oxford University Press; 978-0-19-875937-9 £85

When the Normans arrived in England in AD 1066 they found a kingdom divided into a distinctive and complicated administrative geography. In compiling Domesday Book, the great survey of holdings and liabilities over much of England and parts of Wales completed in 1086, the assessors grouped information firstly into 'shires' - districts that are in many cases the precursors of modern counties - and then into smaller divisions such as hundreds, wapentakes, and vills (estates), with additional groupings such as multiple hundreds and regional ealdormanries also discernible in the source. These administrative entities clearly had a territorial composition. Using the boundaries of estates, parishes, and hundreds mapped at later dates, numerous scholars have sought to reconstruct the administrative geography described in Domesday Book. The resulting maps, in turn, have been interpreted as the product of several centuries of developing territoriality and of continual social and political change. The shires of Norfolk and Suffolk (the 'north' and 'south folk'), for example, appear to fossilise the extents of the kingdom of the East Anglians as it existed three or four hundred years before the Domesday survey; in other cases, clusters of hundreds have been argued to represent post-Roman tribal groupings.

Earlier sources certainly attest to the existence of territorial entities that can, in some cases, be connected with the Domesday geography. The venerable Bede, writing in the early eighth century, used the Latin term provincice to describe larger districts, such as kingdoms, stating that these could also contain smaller regiones. Eagles, in his contribution, connects what Bede refers to as the Meanuarorum prouinciam, "the territory of the dwellers of the (River) Meon" with a group of Domesday hundreds in south-east Hampshire (pp. 163-5). Likewise, Rippon, reconstructs the regio of the Daenningas people - first attested $c$. AD 706-9- to a cluster of hundreds in east Essex (pp. 215-9). Both examples emphasise the point made by historical geographers since at least the nineteenth century: that certain regional identities, persistent until the present day, can be traced into deep time.

Just how far back such regional distinctiveness can be traced is a concern at the heart of both these books - explicitly so in the case of Rippon's Kingdom, Civitas, and County, but also in several of the chapters of Eagles' portmanteaux collection of previously published papers: From Roman Civitas to Anglo-Saxon Shire. Ostensibly, both adopt a comparative approach, plotting objects and diagnostic materials against soils, landcover, relief, and linear earthworks to determine regional patterns. Eagles' focus is on southern England, where he contrasts the distributions of late Roman and early British material culture with those exhibiting 'AngloSaxon' influences. His data is the outcome of over fifty years of research, significantly revised and updated in light of more recent work. Rippon concentrates on an area of central- 
eastern England, but crunches even more data in determining his distributions, including thousands of published finds, Historic Environment Records, grey literature and objects recorded by the Portable Antiquities Scheme. This is one-dimensional, but at times effective, modelling. In Kingdom, Civitas, and County, Rippon plots a huge range of different objects, amongst them Iron Age coins, brooches, ceramics, and loom weights, Roman metalwork and pottery, Anglo-Saxon brooches and sleeve clasps, alongside features such as hillforts, villas, temples, Grubenhäuser and burials to determine that similar regional divisions existed in eastern England during the Iron Age, Roman, and early medieval periods. Looking at a shorter timescale in southern England, Eagles identifies comparable divisions between areas of western and eastern Wessex that persist from the sub-Roman period. Both see the Roman civitas (the major units of local government) as exerting a powerful structuring influence on subsequent territorial development.

Why these territories persist is more difficult to answer. Amongst the more popular models in early medieval studies is that of the 'knock-out competition'. This argues that post-Roman Britain consisted of numbers of relatively small autonomous polities which over the course of the first millennium AD were amalgamated into larger ones, but in doing so, might retain some of their original territorial coherence. Thus, the kingdoms, and ultimately the administrative entities that existed in Domesday Book, fossilise something of the processes by which institutional state power came about. However, one of the problems with this model is that it assumes a relatively pristine starting point in which pre-existing territorial divisions played little part in determining identities, allegiances and obligations. More recently scholars have therefore raised the possibility, indeed the likelihood, that there existed much greater variation and complexity in the processes of kingdom formation. Some areas may have passed relatively smoothly from post-Roman to English rulers, with de facto territorial organisation persisting for some time. Other areas may have undergone a more drawn-out period of fragmentation rather than amalgamation as incoming English leaders took over Romano-British systems of power. Yet other territories may have been reconstituted differently at different times, or retained an ideological or political coherence that is not reflected at all times on the ground.

Of these two books it is Eagles' that expands most on the possible processes involved. In an introduction written specifically for this book, Eagles provides a detailed discussion on the agency of the material culture he is describing, and its uses in signifying ethnicity and identity in the tumultuous periods of the fourth to seventh centuries. The fingerprints of social elites and nascent kingdoms feature large in this and many of the subsequent papers in the collection. The movement of particular objects, the occurrence of distinctive burial assemblages, and their locations relative to resources and routes of communication, are seen as outcomes of the processes by which social capital was harnessed to translate agrarian surpluses into elite culture. In some cases — such as central Hampshire (pp. 157-84) — the territories that emerged thus directly reflected the patterns of social dependency that linked scattered groups of peasants to their lords, who collected and directed renders through their estate centres. In other cases, overlordship over particular peoples and resources was more mutable, requiring physical delineation by use of linear earthworks (e.g. Bokerley Dyke, 
Wansdyke) or displays of power through the occupation of strongholds. In these examples, external warfare is presented as a major driver of state formation, but there is recognition too-visible in the nuanced treatment of early written sources - of how internal dynastic struggles also played their part.

By arguing for an inherent continuity in regional distinctions, Rippon largely side-steps such theoretical debates. Contrasts between regions are explained simply as the result of differences in the density of Anglo-Saxon immigration and the relative survival of native Romano-British populations, or, by the sixth century, in the appearance of regionallydistinctive ethnic groups. A significant issue remains in the equation throughout of archaeological objects and people, or at least the group identities of those who made and used them. There is little discussion of the materiality and agency of these classes of material culture, nor how they might reflect the social dynamics at play. The processes that encouraged and facilitated the maintenance of such territories are never fully explained (though will apparently be expanded upon in a forthcoming companion volume).

In this regard it is a pity that both of the case-studies described in these books focus mainly on the freer draining soils, Chalk downlands and wood-pasture landscapes of eastern and southern England, rather than the heavier soils of the central province. It might be argued that the distribution of resources in the south and east lent itself to the repeated development of political institutions based on more-or-less the same geographical units. Midland England, by contrast, has long been argued to have undergone more significant and cataclysmic phases of reorganisation, as the consequence of - amongst other things - developments in agriculture, settlement nucleation, and political conquests. Can similar forms of territorial continuity be recognised there, and if not, how does one account for the different processes involved?

Taken together, Kingdom, Civitas, and County and From Roman Civitas to Anglo-Saxon Shire represent a good summation of our current evidence for territorial formation from preRoman to early medieval times. Both do an admirable job of drawing on the variety of sources available. Besides the distributions of archaeological materials, use is made of the rich evidence from place-names, written sources, and palaeoenvironmental data. Both also, refreshingly, look beyond the narrow disciplinary confines of 'Early Medieval' or 'Roman' studies to develop a more sophisticated understanding of landscape continuity and change over the long durée. While neither breaks new methodological or theoretical ground, there is plenty of value in the detailed exposition of the evidence in this way. By determining the regional character of southern and eastern England, future studies will be more able to elucidate the contextual interplay between material culture and its uses, territoriality and the political structures that legitimated the claims of elites upon landed resources. Viewed in this way, these topographical studies are just the start of an enquiry, rather than the end of one. 